\title{
Tidewater glacier fluctuations in central East Greenland coastal and fjord regions (1980s-2005)
}

\author{
Hester IISKOOT, ${ }^{1}$ Dan JUHLIN, ${ }^{1}$ Heather ST PIERRE, ${ }^{1}$ Michele CITTERIO ${ }^{2}$ \\ ${ }^{1}$ Department of Geography, University of Lethbridge, Lethbridge, Alberta, Canada \\ E-mail: hester.jiskoot@uleth.ca \\ ${ }^{2}$ Department of Marine Geology and Glaciology, Geological Survey of Denmark and Greenland (GEUS), \\ Copenhagen, Denmark
}

\begin{abstract}
Summer 2000/01 ASTER and Landsat 7 scenes and semi-automated digitization were used to compile a glacier inventory for local glaciers of the Geikie Plateau region, central East Greenland. Of the 332 glaciers $\left(41591 \mathrm{~km}^{2}\right), 120$ are tidewater-terminating and drain $90 \%$ of the glacierized area. Differencing the 2000/01 tidewater margins from the 1980s GEUS map database ice polygons (113 glaciers) and from 2004/05 ASTER tidewater margins (78 glaciers) shows a cumulative tidewater terminus width decrease from $196 \mathrm{~km}$ to $183 \mathrm{~km}$ between the 1980s and 2000s, with a corresponding areal loss of $\sim 31 \mathrm{~km}^{2}$ and an effective length change of $-14.3 \mathrm{~km}$. Between 2000/01 and 2004/05, areal loss was $26 \mathrm{~km}^{2}$. Average margin retreat rate increased two- to threefold, from $1.7-2.1 \mathrm{~km}^{2} \mathrm{a}^{-1}(1980 \mathrm{~s}-$ 2000) to $3.9-5.7 \mathrm{~km}^{2} \mathrm{a}^{-1}$ (2000-05). Advances are negligible, apart from two surges, of which one was previously undetected. Coastal, 'outer' fjord-terminating, glaciers have two to three times larger areal and effective length retreat rates than 'inner' fjord-terminating glaciers. We investigate possible causes and hypothesize that, in addition to ocean temperature and sea ice, changes in sea fog may affect coastal-terminating more than inner fjord-terminating glaciers.
\end{abstract}

\section{INTRODUCTION}

In recent years, tidewater-terminating outlet glaciers in southeast Greenland $\left(\sim 62-67^{\circ} \mathrm{N}\right)$ have displayed synchronous and fast retreat, thinning and in some cases significant increase in flow speed (Luckman and others, 2006; Stearns and Hamilton, 2007; Howat and others, 2008a; Pritchard and others, 2009; Joughin and others, 2010). These glaciers have been the greatest contributor to the almost $50 \%$ increase in runoff from the Greenland ice sheet in the early 2000s (Van den Broeke and others, 2009). The fastest changes took place between 1996 and 2006, with a general slowdown of flow, thinning and retreat since then (Joughin and others, 2010; Murray and others, 2010). The rapid changes may have been a dynamic response to changing surface mass balance (Howat and others, 2008b; Joughin and others, 2008), or a direct response to forcings at the terminus (Nick and others, 2009). Changes in deep Atlantic Ocean currents and sea surface temperatures (SST) have affected fjord water circulation and caused enhanced submarine melting (Murray and others, 2010; Straneo and others, 2010; Christoffersen and others, 2011). In contrast to southeast Greenland, glaciers in northeast Greenland (72$80^{\circ} \mathrm{N}$ ) have not changed significantly (Rignot and Kanagaratnam, 2006; Joughin and others, 2010).

Between the rapidly retreating southeast Greenland glaciers and the stationary northeast glaciers lies central East Greenland $\left(67-72^{\circ} \mathrm{N}\right)$, which contains more than half of the local glaciers peripheral to the Greenland ice sheet $\left(\sim 50000 \mathrm{~km}^{2}\right.$; Jiskoot and others, 2003). This region of extreme relief and complex topography has various glacier types, of which many are tidewater-terminating (Fig. 1). The glaciers are peripheral to the Greenland ice sheet, and therefore smaller and steeper than southeast or northeast Greenland glaciers, and possibly have higher sensitivity to surface mass-balance changes and faster response times. Since the Neoglacial, most land-terminating glaciers have receded up to a few kilometres, but no noticeable changes in most calving fronts occurred up to the mid-1980s (Weidick, 1995). Between 1978 and 1991, some tidewater glaciers retreated slightly $\left(0.1-0.5 \mathrm{~km}^{2}\right.$; Dwyer, 1995). Between $30 \%$ and $70 \%$ of the glaciers are of surge type (Weidick, 1988; Jiskoot and others, 2003), so it is unclear whether terminus fluctuations are glaciodynamic or glacioclimatic responses (Dwyer, 1995). Extreme glaciodynamic terminus fluctuations have occurred in the surging Sortebræ system (Jiskoot and others, 2001), while neighbouring glaciers did not change significantly (Dwyer, 1995; Moon and Joughin, 2008). Some tidewater glaciers have recently increased their flow, but velocities remain low $\left(0.1-2.5 \mathrm{~m} \mathrm{~d}^{-1}\right)$ and suggest quiescence (Dwyer, 1995; Joughin and others, 2010). Recent thinning and increases in mass loss have occurred in the largest glacier systems (Pritchard and others, 2009; Van den Broeke and others, 2009).

Central East Greenland is in a climatic, oceanic and seaice transition zone, which is reflected in the thermal regime of its glaciers (polythermal to temperate) and permafrost (continuous to discontinuous). The transition between the southeast Greenland and drier colder northeast Greenland weather sectors runs through the Geikie Plateau ice divide (Fig. 1; Cappelen and others, 2001; Box and others, 2006). Snowlines are at $\sim 1000-1500$ ma.s.I., and $300-500 \mathrm{~m}$ lower along Blosseville Kyst and Kangerdlugssuaq fjord than along Scoresby Sund (Jiskoot and others, 2003). Sea-ice concentration north of Scoresby Sund is $>80 \%$ throughout the year. To the south it is seasonally variable, and south of Kangerdlugssuaq fjord most sea ice disappears by July (Cappelen and others, 2001). Ocean temperatures and climate along the East Greenland coast are influenced by the cold southward-flowing East Greenland Current (EGC) and East Greenland Coastal Current (EGCC), and the northward-flowing warm saline Irminger Current (IC). The IC turns west towards Greenland where it bifurcates at 
$\sim 66^{\circ} \mathrm{N}$ into a small branch flowing clockwise around Iceland and a larger branch flowing southward along the Greenland continental shelf edge (Azetsu-Scott and Tan, 1997). Since the mid-1990s, warmer and larger volumes of subtropical waters have entered the IC (Straneo and others, 2010). Some of this water penetrated into southeast Greenland fjords and may have caused synchronous changes in its glaciers by influencing fjord stratification, SST and sea-ice distribution (Andrews and others, 2010; Murray and others, 2010; Christoffersen and others, 2011). North of the bifurcation, along Blosseville Kyst, warm deep ocean water penetration is less likely, and is restricted by shallow fjords and fjord sills (Jennings and Weiner, 2006; Andrews and others, 2010). Due to its different glacier types and environmental factors, central East Greenland glacier fluctuations may reveal margin behaviour controls that are not apparent from southeast Greenland glaciers.

In this paper, we present terminus changes of tidewaterterminating glaciers in the Geikie Plateau region of central East Greenland between the 1980s and 2004/05. Novel aspects include tidewater terminus change of a variety of glacier types and sizes over a period of two decades: previous calving front behaviour was measured over shorter periods and only in glaciers with margins wider than $2 \mathrm{~km}$ (Dwyer, 1995; Moon and Joughin, 2008). We further account for surge-type behaviour. We also treat confluent flow units as separate glacier entities and as combined 'fjord systems'. While flow units have individual ice dynamics (e.g. Sortebræ: Jiskoot and others, 2001) the confluent tidewater margin response is often uniform. Furthermore, progressive retreat leads to fragmentation of glaciers and calving margins, which affects ice flow dynamics and calving margin stability (Benn and others, 2007). Finally, pre- and post-2000/ 01 terminus behaviour are compared, and we discuss spatial and temporal patterns of tidewater margin changes in relation to surface mass balance, glacier, sea-ice and ocean dynamics, and glacier type, size and fjord morphology.

\section{METHODOLOGY}

\section{Glacier outlines and tidewater margins}

In order to assess central East Greenland glacier area, tidewater margin fluctuations and sensitivity to climate change, a detailed glacier inventory of the Geikie Plateau region was compiled. Using semi-automated digitization, glacier outlines were extracted from 68 Advanced Spaceborne Thermal Emission and Reflection Radiometer (ASTER) L1B scenes with a spatial resolution of $15 \mathrm{~m}$, and 6 Landsat 7 Enhanced Thematic Mapper Plus (ETM+) pan-sharpened scenes with a resolution of $14.5 \mathrm{~m}$. The global Landsat 7 panchromatic band is orthorectified to an accuracy of $14.25 \mathrm{~m}$ (Tucker and others, 2004). Most ASTER scenes were from late summer 2004/05. May and August 2000 scenes were used to fill in gaps. Landsat 7 scenes were in a coastal strip from 12 July 2000 and an inland strip from 28 August 2001. ASTER scenes were georeferenced to Landsat 7, with the exception of two regions where ASTER-to-ASTER georeferencing was applied due to an absence of cloud-free Landsat 7 scenes. We matched 20 ground-control points distributed in a star-shaped pattern, with a horizontal rootmean-square (RMS) error less than $3.0 \mathrm{~m}$. By georeferencing ASTER to Landsat 7 scenes, the ASTER scenes were resampled to $14.5 \mathrm{~m}$.

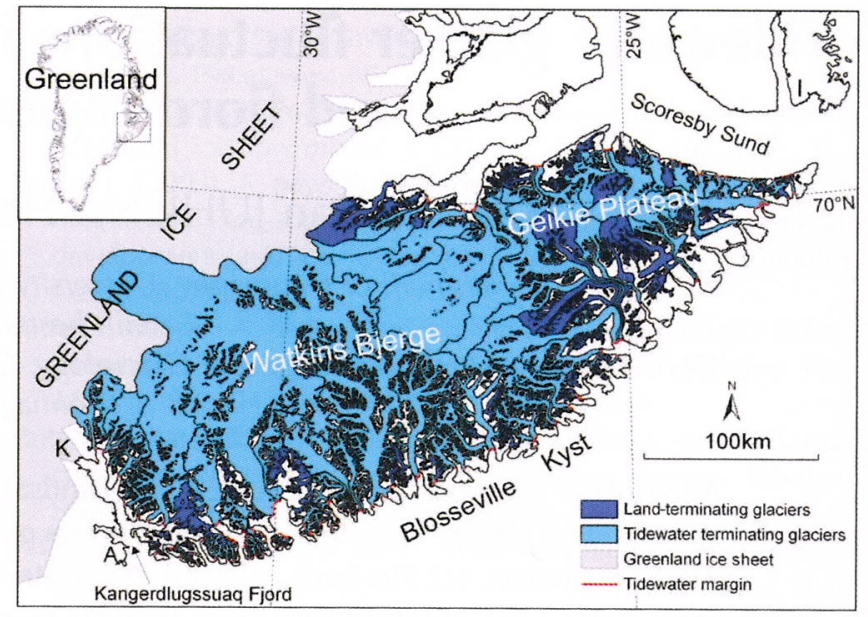

Fig. 1. Study region map with glacier outlines of land-terminating (dark blue) and tidewater-terminating glaciers (light blue) and 2000/01 tidewater margins (red). The outline of the Greenland ice sheet (grey) is approximate and based on Weidick (1995). $\mathrm{K}=$ Kangerdlugssuaq Glacier; $\mathrm{A}$ = Aputiteeq; I = Ittoqqortoomiit.

Although the band ratio method (Paul and others, 2002) is commonly used for semi-automated glacier delineation, we used supervised classification as the separate extraction of snow, ice, fresh water and sea water enabled us to obtain snowlines and lakes for further study. Glaciers were identified from mosaics of two to four ASTER scenes of the same date and gain setting. Training areas of $\geq 1500$ pixels were selected for ten surface classes within each mosaic. These were ultimately grouped into a binary glacier/nonglacier class. The glacier class contained snow and exposed glacier ice. The non-glacier class contained sediment, bedrock, fresh water, vegetation, shadow and sea water. Shaded ice was included in the glacier class, and shaded bedrock/sediment in the non-glacier class, but this shadow filtering was only moderately successful. Systematic comparison of supervised classification tools in ENVI 4.3 revealed that the Maximum Likelihood and Mahalanobis Distance classifications performed best in identifying the glacier class. The Mahalanobis Distance method was ultimately applied because it is faster and less sensitive to the quality of training data (Mutlu and others, 2008). Small polygons and irregularities were removed using the Enhanced Lee Filter with a threshold of $3 \times 3$ pixels. Filtered raster images were converted to polygons and appended into one shapefile in ArcGIS 9.3. A minimum glacier size threshold of $2 \mathrm{~km}^{2}$ was applied because of difficulties distinguishing seasonal snow from glaciers, the small proportion of overall glacierized area and the absence of calving margins in this size group, and for time-management reasons. Because the shapefile exceeded $4 \mathrm{~GB}$, polygons were cleaned using the generalize function with a minimum distance of $100 \mathrm{~m}$. The original file was archived for future use. Significant generalization errors, debris-covered ice, shadow zones and nunataks were manually improved using the Landsat 7 mosaic and the ASTER global digital elevation model (GDEM), a product of the Ministry of Economy, Trade and Industry (METI), Japan, and NASA (http://www.ersdac.or.jp/GDEM/E/). Ice divides were manually delineated from illumination differences, DEM aspect and glaciological interpretation (Racoviteanu and others, 2009). Ultimately, roughly half the glacier outlines were manually digitized. 
Each glacier unit was assigned a GLIMS-ID (Global Land Ice Measurements from Space), based on the east and north decimal degree coordinates of the glacier flowline intersect with the late-summer snowline (http://www.glims.org/ MapsAndDocs/guides.html). GLIMS-ID G333549E68976N (Storbræ) corresponds to point location $68.976^{\circ} \mathrm{N}$, $26.451^{\circ} \mathrm{W}$. Glacier inventory attributes, glacier names and a hydrological basin code (Weidick, 1995) were also assigned. We spatially joined our glacier inventory to its predecessor (Jiskoot, 2002; Jiskoot and others, 2003) and transferred its surge classification, where surge class $0=$ normal glacier (no morphological evidence for surge behaviour), 1 = possibly surge-type (one or two equivocal morphological features of past surge behaviour (e.g. unusual crevasses, some potholes, contorted moraines)), 2 = probably surge-type (two or more unequivocal morphological features of surge behaviour (e.g. tear-shaped moraines, widespread potholes, surge bulge)) and 3 = surge-type (glaciers with an observed surge). For new glaciers, these surge classes were also added, based on the full range of morphological characteristics from Jiskoot and others (2003).

Tidewater glacier margins were manually extracted from July 2000 Landsat 7 and August 2001 ASTER scenes. Where possible, margins were snapped to the glacier outlines derived with the semi-automated method. Tidewater margins from 2004 and 2005 were digitized from ASTER scenes. GEUS map database ice polygons, based on Kort og Matrikelstyrelsen (KMS; Danish Cadastral Survey) aerial photographs from August 1981 and 1987, were used to trace tidewater margins from the 1980s. Because these ice polygons were mapped at a range of scales (1:100000, $1: 250000$ and $1: 500000)$ and by unknown cartographers using aerial photographs of different years, we verified tidewater margins on original aerial photographs (Greenland Aerial Photo Database: http://kmswww3.kms.dk/gronland/ gronland_english.htm). Where confluent tidewater margins formed a continuous calving front, they were assigned a 'fjord system' code and the GLIMS-ID of the main flow unit. Thus, areal and effective length changes (terminus area change divided by the 1980s or 2000/01 margin widths) could be summed for individual glaciers and fjord systems.

Polygons representing areas of retreat or advance were constructed from the overlay of tidewater margin lines from the 1980s, 2000/01 and 2004/05. Because changes were often irregular along tidewater fronts, multiple polygons of advance and retreat occurred at many termini. By assigning all advance/retreat polygons the glacier GLIMS-ID, each advance (positive) or retreat (negative) polygon area was summated using pivot tables in Excel. In this manner, calving-margin area change between the 1980s and 2000/ 01 was obtained for 113 glaciers. Because it was not always clear whether the 1980s margin was mapped from the 1981 or 1987 KMS aerial photographs, we took 1984 as the beginning of this time period, so the time interval 1980s2000/01 was 16 or 17 years. Using the same advance/retreat area summation method, the net areal tidewater margin change was obtained for 78 glaciers for the period 2000/01 to $2004 / 05$ (3-5 year interval).

We minimized the effects of seasonal and interannual fluctuations by using mid- to late-summer scenes only, and by measuring change over relatively long periods. Errors in georeferencing were $0-4$ pixels with an average of 2 pixels $(29 \mathrm{~m})$. Manual digitization errors were within 1 pixel $(14.5 \mathrm{~m})$. The average cumulative error for the ASTER-to-
ASTER or Landsat-7-to-ASTER calving margin is

$$
\sqrt{29.0^{2}+14.5^{2}}=41 \mathrm{~m} \text {. }
$$

Extrapolated over the entire calving margin width $(196 \mathrm{~km})$, this results in an absolute maximum regional error in margin retreat of $8 \mathrm{~km}^{2}$, and a one standard deviation error of $\sim 4 \mathrm{~km}^{2}$.

\section{Fjord morphology}

Fjord width, depth, length and shape can potentially influence tidewater margin stability (Benn and others, 2007) as well as the stability of ice melange, fjord water circulation and the intrusion of deep warm waters (Christoffersen and others, 2011). Due to lateral drag, a widening fjord may lead to a fluctuating ice margin (dynamic equilibrium), while a narrowing fjord may lead to a more stable equilibrium (Benn and others, 2007). Fjord width was approximated by the 1980s calving-margin width. For confluent tidewater margins, the sum of the widths of adjacent calving margins was taken as a proxy. Fjord shape was classified for the first $50-500 \mathrm{~m}$ directly in front of tidewater margins, with class $1=$ tidewater margin at fjord mouth, 2 = fjord width is constant, 3 = fjord widens, and $4=$ fjord narrows away from the margin. Fjord length (distance between tidewater margin and fjord mouth) was measured by digitizing a centre line from the 2000s tidewater terminus to the fjord mouth. Coastal glaciers are more exposed to sea-ice, wind and wave action than inland fjords, secondary fjords and fjords on the lee side of islands. Fjord location may therefore determine the forces acting on calving fronts, including ice melange stability, fjord circulation and sea and air temperature (Murray and others, 2010). Coastal glaciers terminating on Blosseville Kyst are directly exposed to the Atlantic Ocean and were classified as 'outer fjord', unless they were located on the lee side of coastal islands or in secondary-order fjords. These, and glaciers terminating in Kangerdlugssuaq fjord and Scoresby Sund were classified as 'inner fjord'.

\section{RESULTS}

\section{Glacier inventory}

The Geikie Plateau region glacier inventory contains 332 glaciers, with a total area of $41591 \mathrm{~km}^{2}$. Glaciers range in size from $2 \mathrm{~km}^{2}$ (thresholded) to $11079 \mathrm{~km}^{2}$ for Kong Christian IV Gletscher, which partly drains the Greenland ice sheet (Fig. 1). Glacier area is log-normally distributed, and the $2 \mathrm{~km}^{2}$ glacier area threshold underestimates the total glacierized area by only $0.5-1 \%$. Glacier types include ice caps, snowfields, and mountain, valley and outlet glacier systems, of which many are tidewater-terminating. Many glaciers form complex systems, with multiple tributaries and confluent units. Surge evidence is diagnostic for 56 glaciers (classes 2 or 3), and another 75 glaciers were assigned class 1 and are possibly of surge type (see previous section). Hence, we estimate the percentage of surge-type glaciers in the Geikie Plateau region to be $19-44 \%$.

Most large outlet glaciers drain from ice masses at elevations above 2000 ma.s.I. (Geikie Plateau ice cap, icefields around Watkins Bjerge, and the Greenland ice sheet (Kong Christian IV Gletscher)). Smaller glaciers drain from steep coastal cliffs to sea level. Tidewater margin widths range from 0.1 to $10 \mathrm{~km}$, with a total calving-front width of $196 \mathrm{~km}$. 

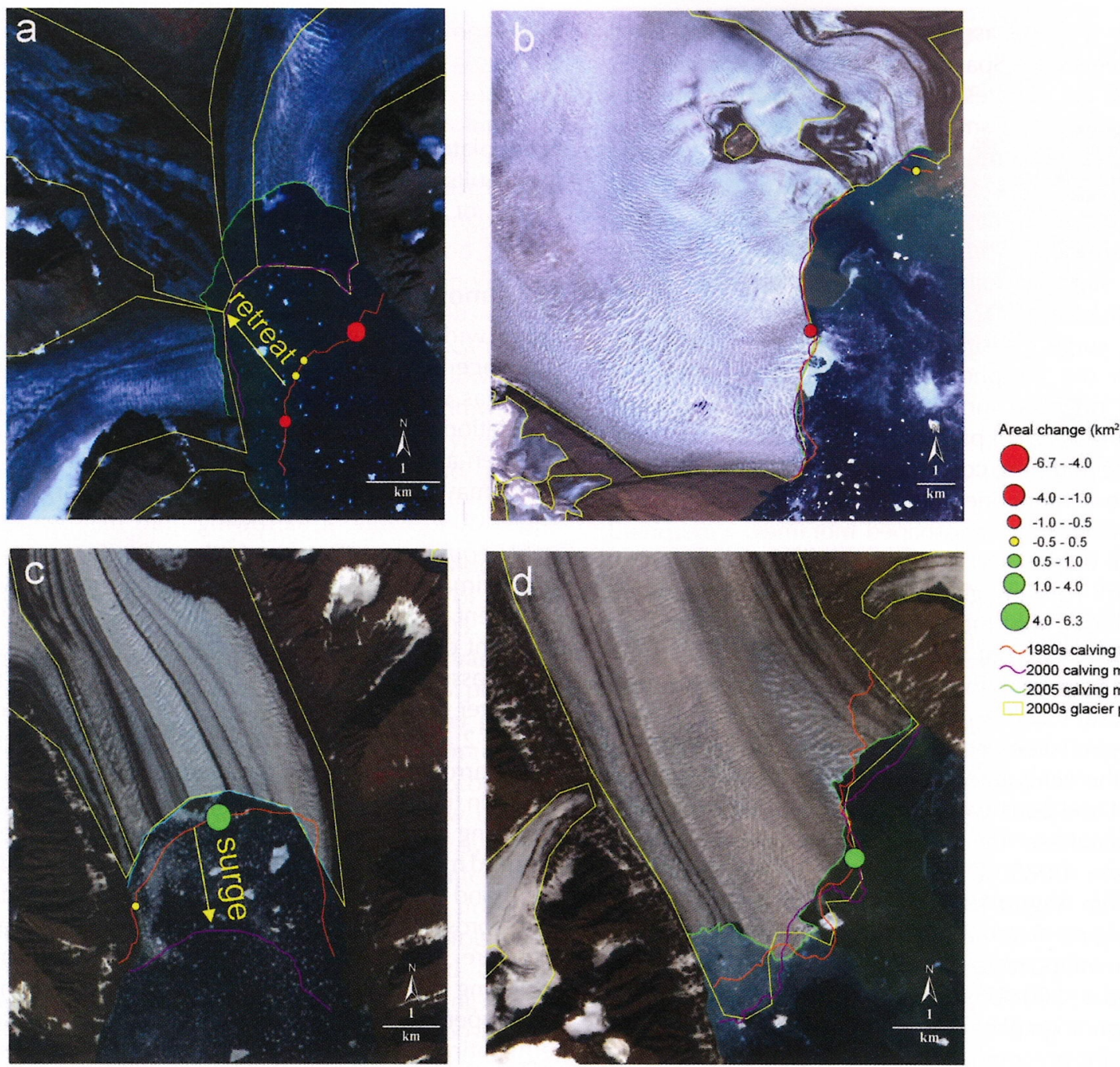

Fig. 2. Tidewater margin changes of (a) unnamed complex in Kivioq Fjord ('Rosenborg Basin'), (b) Kong Christian IV Gletscher, (c) Sortebræ and (d) Borggraven. See Figure 4 for locations. The yellow line is the glacier polygon from the Landsat 7 mosaic of 2000/01. Margin lines are from GEUS map polygons of the 1980s (orange) and ASTER scenes from 2000 (purple) and 2005 (green). Coloured circles correspond to areal retreat or advance between the 1980s and 2000 (Fig. 3a). Backgrounds are 2005 ASTER scenes.

Roughly $90 \%$ of the total glacierized area drains through 120 tidewater glaciers (Fig. 1). It is the first time that these parameters of calving have been quantified in this region.

\section{Calving-margin dynamics}

Between the 1980s and 2000/01, 84 glaciers retreated $\left(-41.3 \mathrm{~km}^{2}\right)$ and 29 glaciers advanced $\left(+10.6 \mathrm{~km}^{2}\right)$, resulting in a net calving area loss of $30.7 \pm 4 \mathrm{~km}^{2}$. The overall yearly retreat rate for these 113 glaciers was $1.9 \mathrm{~km}^{2} \mathrm{a}^{-1}$, but the vast majority (93) did not change significantly $\left(<0.5 \mathrm{~km}^{2}\right.$ over 14-20 years). However, 3 glaciers advanced significantly and 17 glaciers retreated significantly, and 3 small glaciers changed to land-terminating. The maximum retreat occurred in Storbræ S $\left(7.6 \mathrm{~km}^{2}\right.$; Table 1$)$, and the maximum advance in Sortebræ $\left(6.7 \mathrm{~km}^{2}\right.$; Table 1; Fig. 2) due to its 1992-95 surge (Jiskoot and others, 2001). Most other glaciers with retreats more than $1 \mathrm{~km}^{2}$ have some indication of pre-1981 surging behaviour, although no observations of significant surge advances exist (Weidick, 1988; Jiskoot and others, 2003). The largest glacier with retreat more than $1 \mathrm{~km}^{2}$, the non-surge-type Kong Christian IV Gletscher, has a wide tidewater margin $(\sim 10 \mathrm{~km})$ and limited effective length change (Table 1; Fig. 4 further below). Of all other glaciers only four advanced $>0.5 \mathrm{~km}^{2}$. One of these is a newly detected surge of an unnamed former tributary of Bredegletscher (Table 1; 'Tributary Brede'). On KMS aerial photographs from 1981 and 1987, the glacier appears depleted and is land-terminating, hence the surge took place sometime between 1987 and 2000, changing its margin to tidewater-terminating. Due to the lack of ice thickness data in this region, volume losses due to retreat are unattainable.

Between 2000/01 and 2004/05 the cumulative net retreat loss $(n=78)$ was $26.3 \mathrm{~km}^{2}$ with a cumulative annual areal retreat rate of $5.7 \mathrm{~km}^{2} \mathrm{a}^{-1}$. This is approximately a threefold increase in retreat rate compared to the 1980s-2000/01 period $\left(1.7 \mathrm{~km}^{2} \mathrm{a}^{-1}\right.$ for the same 77 glaciers). However, when Sortebræ's surge and retreat are disregarded, these values are $2.1 \mathrm{~km}^{2} \mathrm{a}^{-1}(1980 \mathrm{~s}-2000 / 01)$ and $3.9 \mathrm{~km}^{2} \mathrm{a}^{-1}$ (2000/01-04/05), giving a twofold increase. A total of 46 glaciers retreated $>0.1 \mathrm{~km}^{2}$ (maximum $7.4 \mathrm{~km}^{2}$ for Sortebræ), 44 had no significant change $\left(<0.1 \mathrm{~km}^{2}\right)$ and only one glacier advanced $>0.1 \mathrm{~km}^{2}$ (unnamed G329460E68679N in Kong Christian IV basin). 'Rosenborg Basin', a fjord system with four confluent tidewater margins (Fig. 2; Table 1), doubled its effective length retreat rate from $53 \mathrm{ma}^{-1}$ to $100 \mathrm{~m} \mathrm{a}^{-1}$. The westernmost flow unit, a tributary of 
Table 1. Terminus fluctuations of 16 fjord systems and 11 of the largest non-confluent tidewater glaciers. Glacier names in italic are unofficial. See Figure 4 for locations. Retreat is the areal retreat (negative) or advance (positive) over the time period indicated. $L_{\text {eff }}$ rate is the yearly rate of change in effective length (area divided by tidewater margin width). SUM tallies glaciers with measurements over both time periods (asterisked SUM values exclude Sortebræ). Glaciers are sorted from maximum retreat to maximum advance in the 1980s2000s period

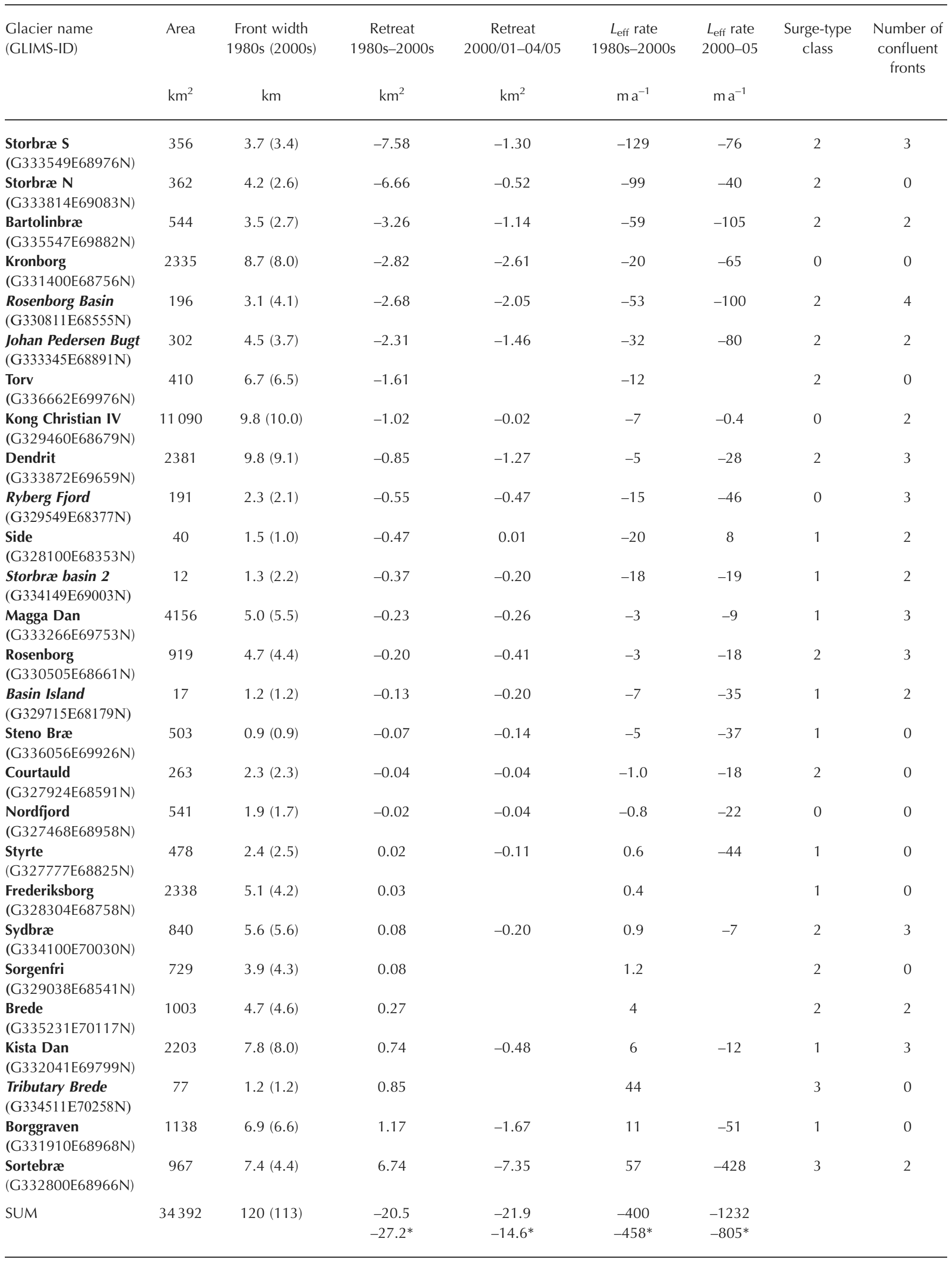



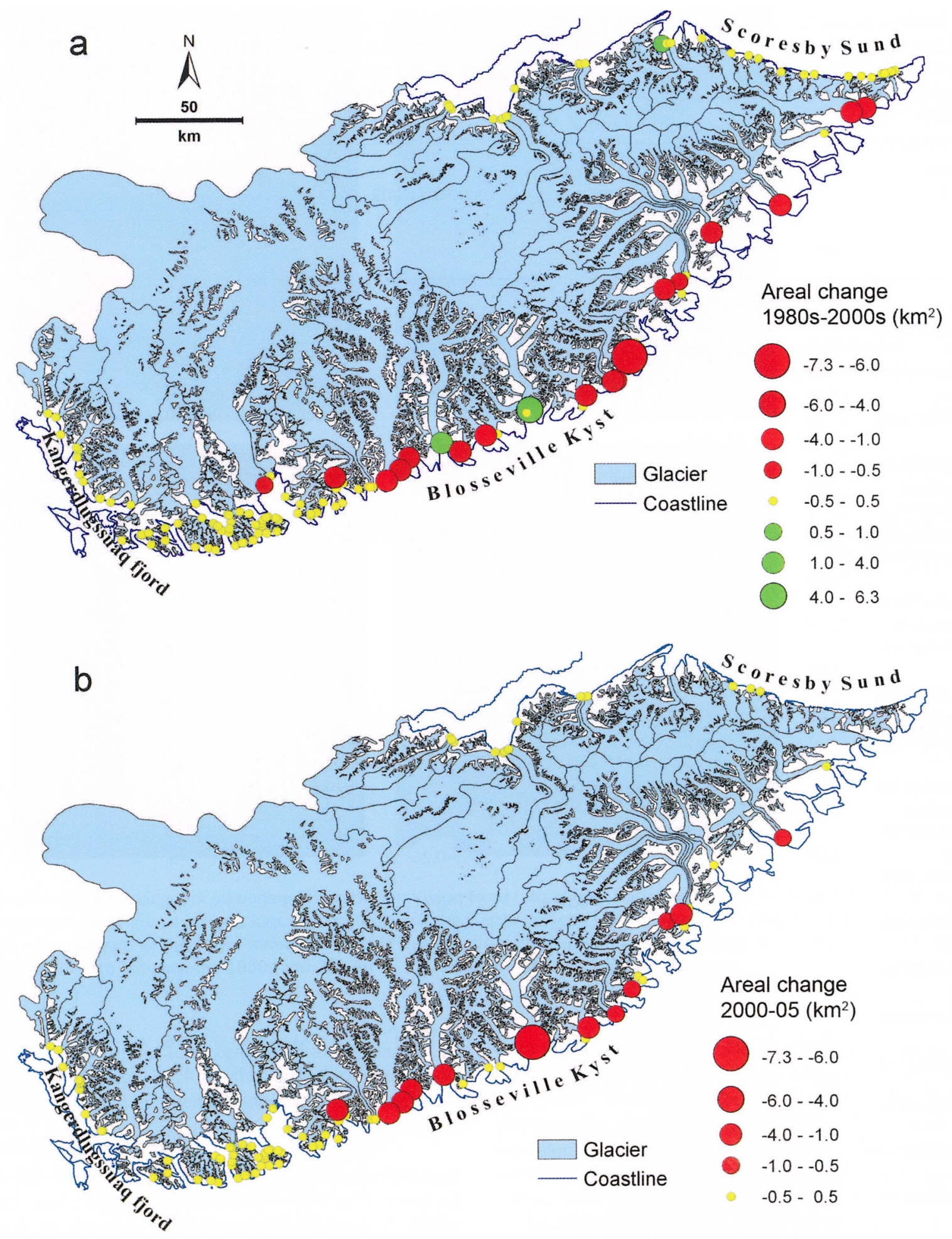

Fig. 3. Tidewater margin area changes for (a) 1980s-2000/01 and (b) 2000/01-04/05. Tidewater margin changes indicated with circles. Colours represent direction (red $=$ retreat, green $=$ advance, yellow $=$ no significant change) and circle size represents magnitude of change.

Rosenborg Gletscher, increased its up-glacier flow speed between 2000/01 and 2005/06, which Joughin and others (2010) suggested may be indicative of surge activity. The rapid multi-year retreat and near-separation of its calving margin may also influence these upstream dynamics.

From the spatial distribution of retreat and advance over both time periods (Fig. 3), it is evident that glaciers along Blosseville Kyst generally have faster retreat rates than those in Scoresby Sund and Kangerdlugssuaq fjord. Increasing retreat rates after 2000/01 occur both in near-stationary margins of the 'inner' fjord-terminating glaciers (e.g. Magga Dan, Kista Dan, Nordfjord and Courtauld) and the nearstationary (e.g. Rosenborg) to significantly retreating (e.g. Bartolinbræ) glaciers along Blosseville Kyst (Fig. 4; Table 1). Exceptions to the increased retreat are Storbræ $\mathrm{N}$ and $\mathrm{S}$ which decreased their retreat rates by $\sim 50 \%$ (Table 1 ). However, these are still some of the fastest-retreating glaciers, and may either have retreated into shallower waters (or a shoal), increasing the basal drag by reduced flotation, or may have slowed their post-surge thinning. 


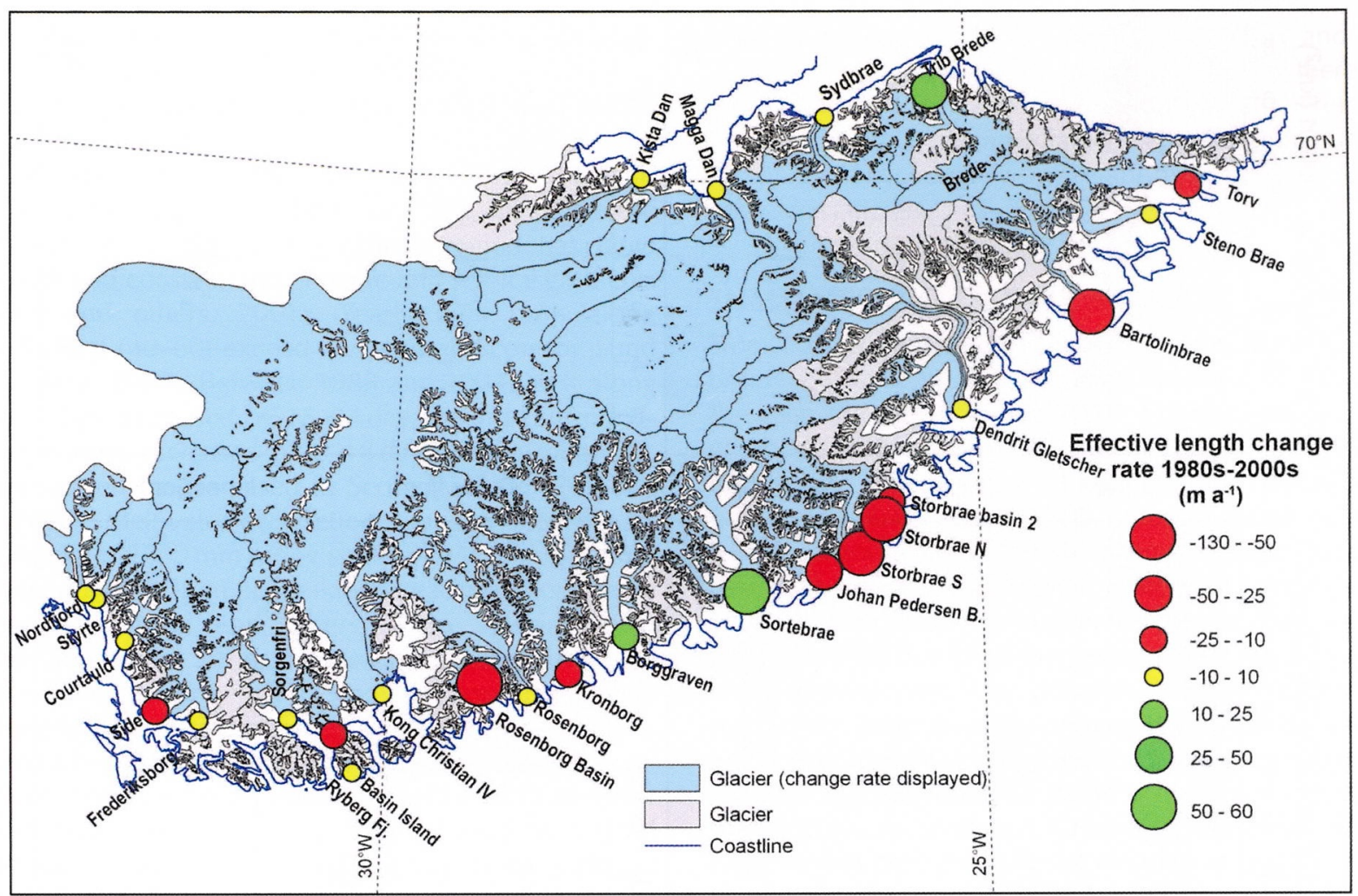

Fig. 4. Effective length rate of change between the 1980 s and 2000/01 for 16 fjord systems and 11 of the largest single glaciers. Names correspond to those in Table 1 and throughout the text.

\section{Glacier type and fjord morphology}

Of the 120 tidewater glaciers, 48 are outlet glaciers, 48 valley glaciers and 24 mountain glaciers. Average glacier areas are $514 \mathrm{~km}^{2}$ (without Kong Christian IV Gletscher), $31 \mathrm{~km}^{2}$ and $4.5 \mathrm{~km}^{2}$ respectively. Confluence is common, and 41 tidewater margins make up 16 fjord systems (each with two to four confluent glaciers; Table 1). The majority of fjords are widening (70) or parallel (19). Only 10 glaciers are in fjords that narrow away from the calving front, and 21 are at the fjord mouth. Fjord lengths range from 0 to $24 \mathrm{~km}$ (excluding the distance to Scoresby Sund and Kangerdlugssuaq fjord mouths). Tidewater glaciers that retreated the most since the 1980s are all in widening or parallel fjords, and most are of the outlet type (Fig. 5). While the largest non-surge advance (Borggraven) occurred in a narrowing fjord, its margin is located at a widening point in the fjord. This $1 \mathrm{~km}^{2}$ advance between the 1980s and $2000\left(11 \mathrm{~m} \mathrm{a}^{-1}\right)$ was followed by a rapid retreat of $1.67 \mathrm{~km}^{2}$ between 2000 and $2005\left(-51 \mathrm{~m} \mathrm{a}^{-1}\right.$ effective length change) (Fig. 2; Table 1). Surge-type glaciers evidently have much higher frontal variability than normal glaciers (Fig. 5). The magnitude of variability appears larger than the general glacioclimatic response over the two decades presented in this paper, as surge-type glaciers with some evidence of pre-1981 surges have amplified retreat rates during their quiescence as compared to normal glaciers. In conformity with the spatial pattern in Figure 3, coastal glaciers ('outer' fjord-terminating) have greater retreat and margin variability than glaciers in inner fjords (Fig. 5). Retreat rates were also correlated with fjord width, length to fjord mouth, glacier area and glacier length (Kong Christian IV, Sortebræ and 'Tributary of Brede' were removed from this analysis). Pearson's correlation statistics suggest that only fjord width has a weak but significant $\left(R^{2}=0.23, \alpha=0.05\right.$, $p=0.000004)$ correlation with retreat; some glaciers in wider, deeper fjords retreat faster.

\section{DISCUSSION}

The widespread pattern of tidewater glacier retreat presented in this paper reflects the overall long-term (1958-2007) regional negative mass balance modelled for the lower to intermediate elevations (Ettema and others, 2009; Van den Broeke and others, 2009). The increase in retreat rate after 2000/01 is potentially related to the North Atlantic Oscillation reversal, which generated increased surface melt after 1995, aided by warming SST and changes in sea-ice distribution (Parkinson and Cavalieri, 2008; Bhattacharya and others, 2009). SST was at a maximum in 2003 in southeast Greenland (Howat and others, 2008b), but did not significantly increase until 2004 in the inner parts of Kangerdlugssuaq and Ryberg fjords (Fig. 4) (Murray and others, 2010). The threefold increase in retreat rate between 1980s-2000 and 2000-05 of 'Ryberg Fjord' (Table 1) may have been a result of this SST warming. Since retreat rates have been much lower in central East Greenland than in southeast Greenland, Blosseville Kyst may indeed be less influenced by deep warm Atlantic Ocean currents (Andrews and others, 2010). Additionally, its (most likely) grounded margins are less sensitive to submarine melt than those at or near flotation in southeast Greenland (Joughin and others, 2008; Nick and others, 2009).

Due to the complex regional topography, ice thickness has only been measured for the largest outlet glacier. The terminus of Kong Christian IV is probably grounded at a $150-200 \mathrm{~m}$ deep shoal, but its bed is at $>600 \mathrm{~m}$ below sea level $20 \mathrm{~km}$ upstream (Jennings and Weiner, 2006; Thomas 

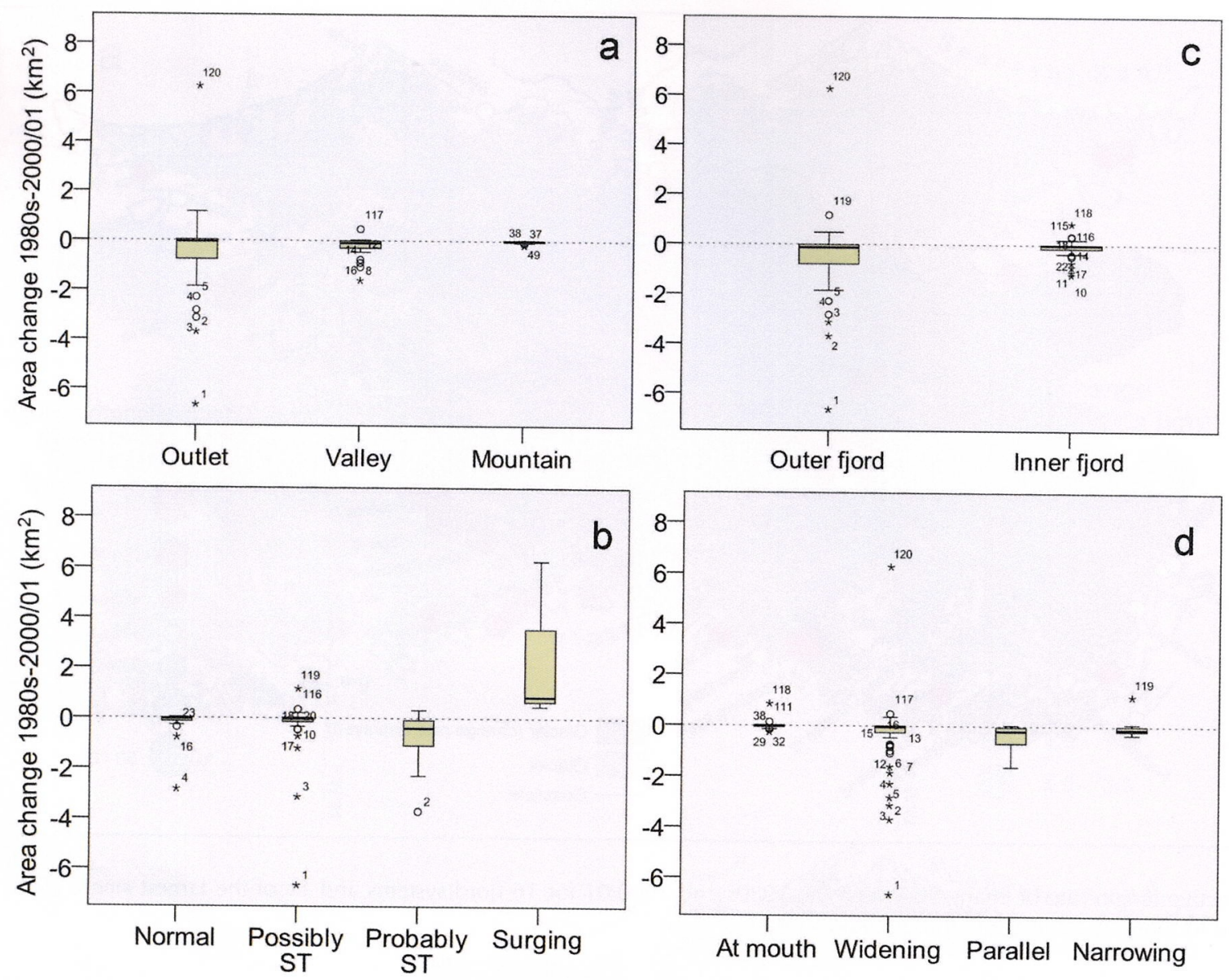

Fig. 5. Box plots of 1980s-2000s change in tidewater margin for different classes of (a) glacier type, (b) surge type (ST), (c) fjord location and (d) fjord shape away from glacier margin. Kong Christian IV Gletscher is omitted.

and others, 2009). Because of this substantial overdeepening, future thinning may result in a runaway retreat when the glacier decouples from its shoal. However, present thinning is limited and decreasing (Pritchard and others, 2009; Thomas and others, 2009). The relatively stationary margins of Kong Christian IV and Magga Dan may also be due to their constant fast flow (Joughin and others, 2010), as margin retreat depends on the interplay between calving rate and ice flow rate (Dwyer, 1995; Luckman and others, 2006).

Blosseville Kyst glaciers with the largest retreat rates also have the large thinning rates and increases in flow speed (Joughin and others, 2010). Storbræ glacier complex (Table 1; Fig. 4) retreats at $99-129 \mathrm{ma}^{-1}$ between the 1980 s and 2000 and $40-76 \mathrm{~m} \mathrm{a}^{-1}$ between 2000 and 2005 (cf. 100-200 $\mathrm{ma}^{-1}$ between 1992 and 2007; Moon and Joughin, 2008) and thins $\sim 5 \mathrm{~m} \mathrm{a}^{-1}$ (Pritchard and others, 2009). Dendrit Gletscher doubled its flow speed between $2000 / 01$ and 2005/06 to $>600 \mathrm{~m} \mathrm{a}^{-1}$ (Joughin and others, 2010). Howat and others (2008a) suggest that such speed-up is initiated by loss of resistive stresses at the front due to thinning and retreat. Although we found a five- to sixfold increase in retreat rate for Dendrit Gletscher, its retreat $\left(1.27 \mathrm{~km}^{2}\right.$ or $140 \mathrm{~m}$ in effective length between 2000 and $2005)$ and thinning rates $\left(1.4 \mathrm{~m} \mathrm{a}^{-1}\right.$, with a dynamic component of $0.85 \mathrm{~m} \mathrm{a}^{-1}$; Pritchard and others, 2009) are still moderate. It is unlikely that these triggered such an increase in flow speed (unless the glacier was near flotation and the terminus at a shallow shoal). It is more likely that the flow speed increased due to internal factors such as upstream interaction of the dendritic flow units or even surge-type behaviour (Weidick, 1995).

Central East Greenland thinning and retreat rates are small compared to those of Kangerdlugssuaq glacier (Fig. 1), which thins $\sim 20-90 \mathrm{~m} \mathrm{a}^{-1}$ and retreated $\sim 5 \mathrm{~km}$ between 2004 and 2005 (Stearns and Hamilton, 2007; Joughin and others, 2008). Kangerdlugssuaq is close to flotation, and its retreat was probably caused by post-2001 thinning which caused flotation and rapid disintegration (Joughin and others, 2008; Thomas and others, 2009). The process may have been amplified by intrusion of warm deep ocean waters (Christoffersen and others, 2011). Although Nordfjord Gletscher, neighbouring Kangerdlugssuaq, almost tripled its retreat rate, it is still marginal $\left(\sim 22 \mathrm{~m} \mathrm{a}^{-1}\right.$ in 2000-01; no data beyond 2001). Nordfjord and Styrte Gletschers are likely exposed to fjord temperatures and sea-ice distribution similar to Kangerdlugssuaq's (see fig. 9 in Murray and others, 2010), but the glaciers are much smaller and drain local ice. Moreover, their flow speed is low $\left(<100 \mathrm{~m} \mathrm{a}^{-1}\right)$ compared to Kangerdlugssuaq (5-14 $\mathrm{km} \mathrm{a}^{-1}$ ) (Rignot and Kanagaratnam, 2006; Joughin and others, 2010). The Nordfjord/Styrte branch of Kangerdlugssuaq fjord is almost devoid of icebergs, but Nordfjord has a persistent sediment plume. This suggests the glacier may be pinned on a shallow shoal.

\section{Possible causes of spatial variability in retreat rates}

While annual variability is large, long-term Greenland Sea summer sea-ice extent has decreased $11 \%$ per decade between 1978 and 2006 (Parkinson and Cavalieri, 2008). As 
sea-ice concentration and surface melt are strongly correlated in central East Greenland (Rennermalm and others, 2009), it may be difficult to separate margin fluctuations resulting from changes in SST and sea ice, from those related to surface mass balance. The spatial pattern of inner and outer fjord tidewater margin behaviour may help identify additional controls. The Geikie Plateau region has large north-south and coast-inland climatic and sea-ice gradients (Cappelen and others, 2001). Yearly melt days along Blosseville Kyst (40-60) exceed those along Scoresby Sund (20-30) (Mote, 2007). Between 1988 and 2004, melt along Blosseville Kyst increased by 18-24 days, melt in surrounding coastal areas increased by $6-18$ days, while melt days were unchanged or decreased in Scoresby Sund (Box and others, 2006). Meltwater production changed accordingly, increasing up to $2000 \mathrm{~mm}$ along south Blosseville Kyst, and decreasing up to $500 \mathrm{~mm}$ on Geikie Plateau and along inner Scoresby Sund (Box and others, 2006). Additionally, Scoresby Sund and Kangerdlugssuaq experience strong katabatic 'föhn' (piteraq) winds from the ice sheet, while alongshore winds dominate the coast (Cappelen and others, 2001). Wind redistributes sea ice, influences ocean swell and waves, and can be an important factor in fjord water circulation (Straneo and others, 2010). Therefore, coastal glaciers and those in inner fjords may have different atmospheric and sea-ice forcings. Moreover, although sea ice is more prevalent along the coast, SST in inland fjords is generally lower due to the relatively high contribution of glacial discharge.

Summer advection fog is frequent along the central East Greenland coast and is related to sea-ice break-up (Brooks, 1979). At coastal stations Ittoqqortoomiit and Aputiteeq (Fig. 1), the May-September average number of fog days per month is 10-21, with the highest frequency in July (Cappelen and others, 2001). Sea breezes bring fog further into the fjords, but there it is quickly dissolved by radiation from the ice-free land. Further, strong off-ice winds remove sea fog and sea ice from fjords, forming a yearly polynya at the mouth of Scoresby Sund. As a result, coastal glaciers are more likely to be influenced by fog, which is known to suppress melt (Brooks, 1979; Mernild and others, 2008). It may be that the strong July correlation between sea-ice concentration and surface melt (Rennermalm and others, 2009) is in part due to the occurrence of sea fog. We observed coastal fog on our satellite imagery and on JulyAugust MODIS quicklooks in other years. In years with low summer sea-ice concentration, coastal glaciers may experience enhanced melt while fjord-terminating glaciers will not, as sea fog is always more sporadic in fjords. Thus, variability in sea ice not only influences SST and wave action (dynamics at the tidewater terminus), but also the amount and frequency of coastal fog (surface melt). Trend analysis of fog days in East Greenland, and correlations to glacier behaviour and other factors may help unravel causes for differences in coastal and fjord-terminating glacier behaviour.

Another potential explanation of the differences may be derived from hypsometric analysis. From the ASTER GDEM we derived that glaciers north of the Geikie Plateau ice divide are more top-heavy and have steeper slopes at low elevations than along Blosseville Kyst. Outlet glaciers along Scoresby Sund and Kangerdluggsuaq have their lower 10$20 \mathrm{~km}$ below $1000 \mathrm{~m}$ a.s.I., while along Blosseville Kyst it can be $30-50 \mathrm{~km}$. This, in combination with a lower albedo and a southerly aspect, results in a wider zone of negative mass balance along Blosseville Kyst (e.g. Box and others, 2006). Thinning and meltwater production may therefore be more important for the coastal region. It may therefore also be useful to study average glacier slope (Joughin and others, 2010) and hypsometry in relation to the response of tidewater glaciers.

\section{SUMMARY AND CONCLUSIONS}

Tidewater-terminating glaciers in central East Greenland drain $\sim 90 \%$ of the total glacierized area of $41591 \mathrm{~km}^{2}$. Between the 1980s and 2000/01 the total calving margin width decreased from $196 \mathrm{~km}$ to $183 \mathrm{~km}$, and tidewaterterminating glaciers lost $31 \mathrm{~km}^{2}$ of their terminus area. Between 2000/01 and 2004/05, at least another $26 \mathrm{~km}^{2}$ was lost. Areal and effective length changes increased on average two- to threefold after 2000/01. Maximum retreat rates (50$100 \mathrm{~m} \mathrm{a}^{-1}$ ) occurred in less than ten glaciers. Any significant advances were due to two surges, of which one had not been reported previously. Surge dynamics, whether during surge or quiescence, emerge as the primary control on the variability and trend in tidewater terminus positions in this region. Central East Greenland glaciers have not retreated as dramatically as southeast Greenland outlet glaciers. This suggests that changes in ocean circulation and SST have not been of the same magnitude this far north, corroborating that the $I C^{\prime}$ 's influence diminishes north of $67^{\circ} \mathrm{N}$.

Coastal glaciers have two to three times larger retreat rates than inner fjord-terminating glaciers. We suggest possible reasons for this spatial distribution that include ocean and SST temperature and sea-ice distribution. We propose two novel potential controls: the spatial and temporal distribution of sea fog, and differences in ablation rates related to hypsometry. Investigations into causal relationships between these factors are currently underway. Unravelling possible correlations between tidewater margin response and driving forces (climate, ocean temperature and circulation, and SST and sea-ice distribution) at daily, annual and decadal scales will benefit from long-term and hightemporal-resolution analysis of tidewater margin behaviour in a wide range of glacier sizes and environments.

\section{ACKNOWLEDGEMENTS}

Funding was through a Natural Sciences and Engineering Research Council of Canada (NSERC) Discovery Grant, NSERC University Faculty Award and a Government of Alberta STEP grant. Access to ASTER imagery was made possible by H.J.'s affiliation with the GLIMS consortium, through which the central East Greenland glacier inventory will be distributed. Useful suggestions by scientific editor Helen Fricker, Ute Herzfeld and an anonymous reviewer helped improve the paper.

\section{REFERENCES}

Andrews JT, Jennings AE, Coleman GC and Eberl DD (2010) Holocene variations in mineral and grain-size composition along the East Greenland glaciated margin $\left(\right.$ ca $\left.67^{\circ}-70^{\circ} \mathrm{N}\right)$ : local versus long-distance sediment transport. Quat. Sci. Rev., 29(19-20), 2619-2632 (doi: 10.1016/j.quascirev.2010.06.001)

Azetsu-Scott K and Tan FC (1997) Oxygen isotope studies from Iceland to an East Greenland Fjord: behaviour of glacial meltwater plume. Mar. Chem., 56(3-4), 239-251 (doi: 10.1016/S0304-4203(96)00078-3) 
Benn DI, Warren CW and Mottram RH (2007) Calving processes and the dynamics of calving glaciers. Earth-Sci. Rev., 82(3-4), 143-179 (doi:10.1016/j.earscirev.2007.02.002)

Bhattacharya I, Jezek KC, Wang L and Liu H (2009) Surface melt area variability of the Greenland ice sheet: 1979-2008. Geophys. Res. Lett., 36(20), L20502 (doi: 10.1029/ 2009GL039798)

Box JE and 8 others (2006) Greenland ice sheet surface mass balance variability (1988-2004) from calibrated polar MM5 output. J. Climate, 19(12), 2783-2800

Brooks CK (1979) Geomorphological observations at Kangerdlugssuaq, East Greenland. Medd. Grønl. Geosci. 1

Cappelen J, Jørgensen BV, Laursen EV, Stannius LS and Thomsen RS (2001) The observed climate of Greenland, 1958-99 - with climatological standard normals, 1961-90. Danish Meteorological Institute, Ministry of Transport, Copenhagen (Tech. Rep. 00-18)

Christoffersen P and 7 others (2011) Warming of waters in an East Greenland fjord prior to glacier retreat: mechanisms and connection to large-scale atmospheric conditions. Cryosphere, 5(3), 701-714 (doi: 10.5194/tc-5-701-2011)

Dwyer JL (1995) Mapping tidewater glacier dynamics in East Greenland using Landsat data. J. Glaciol., 41(139), 584-595

Ettema J and 6 others (2009) Higher surface mass balance of the Greenland ice sheet revealed by high-resolution climate modelling. Geophys. Res. Lett., 36(L12), L12501 (doi: 10.1029/ 2009GL038110)

Howat IM, Smith BE, Joughin I and Scambos TA (2008a) Rates of southeast Greenland ice volume loss from combined ICESat and ASTER observations. Geophys. Res. Lett., 35(17), L17505 (doi: 10.1029/2008GL034496)

Howat IM, Joughin I, Fahnestock M, Smith BE and Scambos T (2008b) Synchronous retreat and acceleration of southeast Greenland outlet glaciers 2000-2006: ice dynamics and coupling to climate. J. Glaciol., 54(187), 646-660 (doi: 10.3189/ 002214308786570408)

Jennings AE and Weiner NJ (2006) Environmental change in eastern Greenland during the last 1300 years: evidence from foraminifera and lithofacies in Nansen Fjord, $68^{\circ} \mathrm{N}$. Holocene, 6(2), 179-191 (doi: 10.1177/095968369600600205)

Jiskoot H (2002) Central East Greenland GLIMS Glacier Database. National Snow and Ice Data Center/World Data Center for Glaciology, Boulder, CO. Digital media

Jiskoot H, Pedersen AK and Murray T (2001) Multi-model photogrammetric analysis of the 1990s surge of Sortebræ, East Greenland. J. Glaciol., 47(159), 677-687 (doi: 10.3189/ 172756501781831846)

Jiskoot H, Murray T and Luckman A (2003) Surge potential and drainage-basin characteristics in East Greenland. Ann. Glaciol., 36, 142-148 (doi: 10.3189/172756403781816220)

Joughin I and 8 others (2008) Ice-front variation and tidewater behavior on Helheim and Kangerdlugssuaq Glaciers, Greenland. J. Geophys. Res., 113(F1), F01004 (doi: 10.1029/2007JF000837)

Joughin I, Smith BE, Howat IM, Scambos T and Moon T (2010) Greenland flow variability from ice-sheet-wide velocity mapping. J. Glaciol., 56(197), 415-430

Luckman A, Murray T, de Lange R and Hanna E (2006) Rapid and synchronous ice-dynamic changes in East Greenland. Geophys. Res. Lett., 33(3), L03503 (doi: 10.1029/2005GL025428)

Mernild SH, Hansen BU, Jakobsen BH and Hasholt B (2008) Climatic conditions at the Mittivakkat Glacier catchment (19942006), Ammassalik Island, southeast Greenland, and in a 109year perspective (1898-2006). Geogr. Tidsskr., 108(1), 51-72
Moon T and Joughin I (2008) Changes in ice front position on Greenland's outlet glaciers from 1992 to 2007. J. Geophys. Res., 113(F2), F02022 (doi: 10.1029/2007JF000927)

Mote TL (2007) Greenland surface melt trends 1973-2007: evidence of a large increase in 2007. Geophys. Res. Lett., 34(22), L22507 (doi: 10.1029/2007GL031976)

Murray T and 10 others (2010) Ocean regulation hypothesis for glacier dynamics in southeast Greenland and implications for ice sheet mass changes. J. Geophys. Res., 115(F3), F03026 (doi: 10.1029/2009JF001522)

Mutlu M, Popescu SC, Stripling C and Spencer T (2008) Mapping surface fuel models using lidar and multispectral data fusion for fire behavior. Remote Sens. Environ., 112(1), 274-285 (doi: 10.1016/j.rse.2007.05.005)

Nick FM, Vieli A, Howat IM and Joughin I (2009) Large-scale changes in Greenland outlet glacier dynamics triggered at the terminus. Nature Geosci., 2(2), 110-114 (doi: 10.1038/ ngeo394)

Parkinson CL and Cavalieri DJ (2008) Arctic sea ice variability and trends, 1979-2006. J. Geophys. Res., 113(C7), C07003 (10.1029/2007JC004558)

Paul F, Kääb A, Maisch M, Kellenberger T and Haeberli W (2002) The new remote-sensing-derived Swiss glacier inventory: I. Methods. Ann. Glaciol., 34, 355-361

Pritchard HD, Arthern RJ, Vaughan DG and Edwards LA (2009) Extensive dynamic thinning on the margins of the Greenland and Antarctic ice sheets. Nature, 461(7266), 971-975 (doi: 10.1038/nature08471)

Racoviteanu AE, Paul F, Raup B, Khalsa SJS and Armstrong R (2009) Challenges and recommendations in mapping of glacier parameters from space: results of the 2008 Global Land Ice Measurements from Space (GLIMS) workshop, Boulder, Colorado, USA. Ann. Glaciol., 50(53), 53-69 (doi: 10.3189/ 172756410790595804)

Rennermalm AK, Smith LC, Stroeve JC and Chu VW (2009) Does sea ice influence Greenland ice sheet surface-melt? Environ. Res. Lett., 4(2), 024011 (doi: 10.1088/1748-9326/4/2/ 024011)

Rignot E and Kanagaratnam P (2006) Changes in the velocity structure of the Greenland Ice Sheet. Science, 311(5673), 986-990 (doi: 10.1126/science.1121381)

Stearns LA and Hamilton GS (2007) Rapid volume loss from two East Greenland outlet glaciers quantified using repeat stereo satellite imagery. Geophys. Res. Lett., 34(5), L05503 (doi: 10.1029/2006GL028982)

Straneo F and 7 others (2010) Rapid circulation of warm subtropical waters in a major glacial fjord in East Greenland. Nature Geosci., 3(33), 182-186 (doi: 10.1038/ngeo764)

Thomas R, Frederick E, Krabill W, Manizade S and Martin C (2009) Recent changes on Greenland outlet glaciers. J. Glaciol., 55(189), 147-162 (doi: 3189.002214309788608958)

Tucker CJ, Grant DE and Dykstra JD (2004) NASA's global orthorectified Landsat data set. Photogramm. Eng. Remote Sens., 70(3), 313-322

Van den Broeke $M$ and 8 others (2009) Partitioning recent Greenland mass loss. Science, 326(5955), 984-986 (doi: 10.1126/science.1178176)

Weidick A (1988) Surging glaciers in Greenland: a status. Grønl. Geol. Unders. Rapp. 140, 106-110

Weidick A (1995) Greenland. In Williams RS, Jr and Ferrigno J eds. Satellite image atlas of glaciers of the world. US Geological Survey, Denver, CO, C1-C105 (USGS Professional Paper 1386-C) 